JURNAL PENDIDIKAN, p-ISSN 2715-095X, e-ISSN 2686-5041

Volume 30, No.2, Juli 2021 (273-282)

Online: http://journal.univetbantara.ac.id/index.php/jp

\title{
Penerapan Pembelajaran Direct Instruction untuk Meningkatkan Hasil Belajar IPA Ciri Ciri Makhluk Hidup Siswa Kelas III SDN Nguter 01
}

\section{Kartika Kurniasari Sasmoko}

SDN Nguter 01, Kabupaten Sukoharjo, Email: koertika@gmail.com

Received: Mey 27, 2021

Accepted: Juni 2, 2021

Online Published: Juni 26, 2021

\begin{abstract}
Abstrak:Penelitian dilatarbelakangi oleh rendahnya hasil belajar IPA siswa kelas III SDN Nguter 01Penelitian ini bertujuan untuk meningkatkan hasil belajar IPA materi ciri-ciri makhluk hidup pada siswa kelas III SDN Nguter 01, Sukoharjo Semester I tahun pelajaran 2019/2020 melalui Penggunaan Model Pembelajaran Kooperatif DIMetode penelitian ini menggunakan Penelitian Tindakan Kelas yang dilakukan dalam 4 alur kegiatan, meliputi tahap kegiatan perencanaan, tahap pelaksanaan, tahap tindakan, pengamatan, dan yang terakhir adalah tahap refleksi. Lembar instrumen yang digunakan adalah perangkat tes,dan lembar observasi, yang digunakan untuk mengamati aktivitas belajar siswa. Berdasarkan hasil analisis dari penelitian ini dapat disimpulkan bahwa melalui penggunaan model Pembelajaran Kooperatif (DI) dapat meningkatkan dapat meningkatkan hasil belajar IPA Materi Ciri-Ciri Makhluk Hidup Siswa Kelas III SDN Nguter 01 Sukoharjo Semester I Tahun Pelajaran 2019/2020. Terjadi peningkatan nilai rata-rata sebesar 12,5 dan peningkatan ketuntasan sebesar $35 \%$ dari kondisi awal sampai pada akhir siklus II
\end{abstract}

Kata-kata Kunci: direct instruction, hasil belajar, IPA

\section{Application of Direct Instruction Learning to Improve Science Learning Outcomes the Characteristics of Living Creatures of Class III Students of SDN Nguter 01}

\section{Kartika Kurniasari Sasmoko}

SDN Nguter 01, Sukoharjo Regency, email: koertika@gmail.com

\begin{abstract}
The research is motivated by the low science learning outcomes of grade III students at SDN Nguter 01 This research aims to improve the learning outcomes of science learning material on the characteristics of living things in grade III SDN Nguter 01, Sukoharjo Semester I of the 2019/2020 academic year through the use of Direct Instruction Cooperative Learning Model (DI) This research method uses Classroom Action Research which is carried out in 4 activity lines, including the planning activity stage, the implementation stage, the action stage, observation, and the last is the reflection stage. The instrument sheets used are test kits and observation sheets, which are used to observe student learning activities. Based on the results of the analysis of this study, it can be concluded that through the use of the DI Cooperative Learning model, it can improve the science learning outcomes of Class III Students of SDN Nguter 01 Sukoharjo Semester I Academic Year 2019/2020. There was an increase in the average value of 12.5 and an increase in completeness by $35 \%$ from the initial conditions to the end of cycle II
\end{abstract}

Keywords: direct instruction, learning outcomes, science 


\section{Pendahuluan}

Pendidikan pada hakekatnya adalah pemberian bantuan kepada orang lain secara sadar dan terencana untuk mewujudkan dan mengaktifkan potensi orang lain, agar yang bersangkutan memiliki kekuatan spiritual keagamaan, pengendalian diri, kepribadian, kecerdasan, akhlak mulia serta keterampilan yang diperlukan dirinya, masyarakat, bangsa dan Negara. Semakin maju tingkat pendidikan seseorang, maka semakin siap pula menghadapi perkembangan ilmu pengetahuan dan teknologi di masa depan yang penuh ketidakpastian. Perkembangan Ilmu Pengetahuan dan Teknologi tidak pasti itulah menuntut tiap-tiap warga negara berhak mendapatkan pengajaran di bidang pedidikan (Suwarto, 2017). Masalah interaksi di kelas, yaitu komunikasi antara guru dan murid dalam proses belajar mengajar di kelas merupakan masalah pendidikan yang sangat menarik untuk dibicarakan yang sampai kini tidak pernah ada habisnya. Pada kenyataannya saat ini seringkali di dalam proses belajar mengajar kurang memberikan kesempatan kepada siswa untuk mengembangkan diri sesuai dengan taraf kemampuannya. Oleh sebab itu dikembangkan metode mengajar yang melibatkan siswa lebih aktif dalam proses belajar mengajar, Oleh karena itu bagi para pendidik serta pengelola pendidikan senantiasa diharapkan pemecahannya guna menuju proses belajar mengajar dapat terlaksana dengan baik. Mata pelajaran IPA merupakan salah satu mata pelajaran yang diajarkan di sekolah dasar, dan merupakan hasil kegiatan manusia berupa pengetahuan, gagasan dan konsep yang terorganisasi tentang alam sekitar, yang diperoleh dari pengalaman melalui serangkaian proses ilmiah antara lain penyelidikan, penyusunan dan pengujian gagasangagasan (Suprapti Hariyani, 2019).

Peneliti mengidentifikasi kelemahan dan kesulitan belajar itu disebabkan kurangnya bervariasinya model pembelajaran IPA, hal ini dibuktikan rendahnya hasil ulangan harian IPA siswa kelas III SDN Nguter 01 semester I tahun pelajaran 2019/2020 sejumlah 20 siswa yang tuntas hanya 13 siswa, dengan prosentase ketuntasan hanya $65 \%$. dengan kriteria ketuntasan minimal yaitu tujuh puluh. Berdasarkan latar belakang masalah di atas maka peneliti tertarik untuk mengkaji lebih dalam tentang Penggunaan Model Pembelajaran Kooperatif DI) dalam Meningkatkan Hasil Belajar IPA Tentang Ciri-Ciri Makhluk Hidup Siswa Kelas III SDN Nguter 01 Tahun Pelajaran 2019/2020.

Penelitian yang dilakukan oleh Garnawati Siregar (2016) dalam Jurnal Primary Program Studi Pendidikan Guru Sekolah Dasar Fakultas Keguruan dan Ilmu Pendidikan Universitas Riau menyatakan belajar merupakan suatu proses belajar usaha yang dilakukan seseorang untuk memperoleh suatu perubahan baru yang akan dianggap sebagai pengalamannya supaya dapat berinteraksi dan berkomunikasi di dalam suatu lingkungan. Sedangkan belajar menurut Avikasari (2015) yang dituangkan dalam jurnal theory intro practice menjelaskan bahwa belajar merupakan sebuah perubahan perilaku sebagai hasil kebiasaan kepribadian dan pengalaman hidup yang dialami individu di lingkungannya. Belajar sangat erat hubungannya dengan sebuah pengalaman, karena dari sebuah pengalaman atau kebiasaan yang sering dialami oleh siswa dalam kehidupan sehari-hari, maka siswa akan dapat mengerti sesuatu hal. Belajar tidak akan terlepas dari diri seseorang, karena belajar adalah sebuah kegiatan yang akan berlangsung seumur hidup Morgan dalam Sutikno (2013) mengartikan belajar merupakan suatu perubahan tingkah laku sebagai akibat dari hasil pengalamananya sendiri yang diperoleh di masa lalu yang akan berlangsung lama. Sardiman (2010:20) mengartikan belajar merupakan upaya dalam menguasai ilmu pengetahuan yang merupakan bagian dari proses menuju membentuk 
kepribadian seseorang seutuhnya. Senada dengan pendapat tersebut Slameto (2010:2) menuliskan dalam sebuah buku arti dari belajar adalah suatu langkah langkah dalam upaya yang dilakukan seseorang menuju perubahan tingkah laku secara utuh, sebagai hasil pengalaman seseorang tersebut dalam kehidupan bermasyarkat. Selain itu Sardiman (2010: 20) menyatakan bahwa belajar merupakan suatu perubahan tingkah laku atau penampilan, dengan serangkaian kegiatan misalnya dengan membaca, mengamati, mendengarkan, meniru dan lain sebagainyaBelajar diartikan perubahan tingkah laku pada diri individu berkat adanya interaksi antara individu satu dengan individu lain dan individu dengan lingkungannya sehingga mereka lebih mampu berinteraksi dengan lingkungannya Burton (dalam Susanto, 2013: 3). Belajar adalah suatu perubahan kegiatan reaksi terhadap lingkungan. Perubahan kegiatan yang dimaksudkan mencakup pengetahuan, kecakapan, tingkah laku, dan ini diperoleh melalui latihan (pengalaman). Belajar juga merupakan proses mencari ilmu yang terjadi dalam diri seseorang melalui latihan, pembiasaan, pengalaman dan sebagainya menurut E.R. Hilgard (dalam Susanto, 2013: 3). Kingsley (dalam Susanto, 2013: 3) membagi hasil belajar menjadi tiga macam, yaitu: (1) keterampilan dan kebiasaan; (2) pengetahuan dan pengertian; (3) sikap dan cita-cita. Sedangkan Djamarah dan Zain (dalam Susanto, 2013: 3) menetapkan bahwa hasil belajar telah tercapai apabila telah terpenuhi dua indikator berikut, yaitu: Daya serap terhadap bahan pengajaran yang diajarkan mencapai prestasi tinggi, baik secara individual maupun kelompok; Perilaku yang digariskan dalam tujuan pengajaran /instruksional khusus telah dicapai oleh siswa baik secara individu maupun kelompok.Belajar adalah suatu aktivitas mental yang berlangsung dalam interaksi aktif antara seseorang dengan lingkungan, dan menghasilkan perubahan-perubahan dalam pengetahuan, pemahaman, dan keterampilan, dan nilai sikap yang bersifat relatif konstan dan berbekas. Jadi apabila pada diri orang lain terjadi suatu kegiatan yang dapat mengakibatkan perubahan tingkah laku yang berkaitan dengan hal tersebut. W.S. Winkel (dalam Susanto, 2013: 4).Dari beberapa pengertian belajar di atas, dapat ditarik kesimpulan bahwa belajar adalah suatu aktivitas yang dilakukan seseorang dengan sengaja dalam keadaan sadar untuk memperoleh suatu konsep, pemahaman, atau pengetahuan baru sehingga memungkinkan seseorang terjadinya perubahan perilaku yang relatif tetap baik dalam berfikir, merasa, maupun dalam bertindak. Berdasarkan uraian tentang konsep belajar di atas, dapat dipahami tentang makna hasil belajar, yaitu perubahan-perubahan yang terjadi pada diri siswa, baik yang menyangkut aspek kognitif, afektif dan psikomotor sebagai hasil dari kegiatan belajar. Pengertian tentang hasil belajar sebagaimana diuraikan di atas dipertegas oleh Menurut Sudjana (2010: 22), hasil belajar adalah kemampuan yang dimiliki siswa setelah menerima pengalaman belajar. Sehubungan dengan pendapat itu, maka Wahidmurni, dkk. (2010: 18) menjelaskan bahwa sesorang dapat dikatakan telah berhasil dalam belajar jika ia mampu menunjukkan adanya perubahan dalam dirinya. Perubahan-perubahan tersebut di antaranya dari segi kemampuan berpikirnya, keterampilannya, atau sikapnya terhadap suatu objek. Hasil belajar tampak sebagai dampak dari terjadinya perubahan tingkah laku pada diri siswa. Perubahan tersebut dapat diartikan bahwa terjadi peningkatan dan pengembangan yang lebih baik dibandingkan dengan sebelumnya dan perubahan tersebut dapat diamati setelah dilakukan penilaian. Penilaian bertujuan sebagai cermin untuk melihat kembali apakah tujuan yang ditetapkan telah tercapai dan apakah proses belajar mengajar telah berlangsung efektif untuk memperoleh hasil belajar (Suprijono 2010: 47). Menurut Winaputra (2005) mengartikan hasil perubahan pola tingkah laku berupa penguasaan nilai sikap motorik, pengetahuan dan keterampilan. Untuk mengetahui hasil belajar seseorang dapat dilakukan 
dengan melakukan tes dan pengukuran. Tes dan pengukuran memerlukan alat sebagai pengumpul data yang disebut dengan instrumen penilaian hasil belajar. Menurut Wahidmurni, dkk. (2010: 28), instrumen dibagi menjadi dua bagian besar, yakni tes dan non tes. Selanjutnya, menurut Hamalik (2006: 155), memberikan gambaran bahwa hasil belajar yang diperoleh dapat diukur melalui kemajuan yang diperoleh siswa setelah belajar dengan sungguh-sungguh. Hasil belajar tampak terjadinya perubahan tingkah laku pada diri siswa yang dapat diamati dan diukur melalui perubahan sikap dan keterampilan. Perubahan tersebut dapat diartikan terjadinya peningkatan dan pengembangan yang lebih baik dibandingkan dengan sebelumnya. Semua hasil belajar tersebut merupakan hasil dari suatu interaksi tindak belajar dan tindak mengajar. Hasil belajar hendaknya dapat dilaksanakan di suatu kelas dan di luar kelas, dalam hal ini hasil belajar ditekankan agar hasil belajar tersebut dapat di informasikan atau digunakan di dalam kehidupan bermasyrakat Hamalik (2010: 31-32). Hasik belajar pada dasarnya merupakan kemampuan siswa dalam hal memahami pelajaran, pemahaman siswa tentang suatu hal dan mengubah perilaku siswa tersebut menjadi lebih baik, dan dibuktikan dalam suatu hasil yang nyata. Dari sisi guru, tindak mengajar di akhiri dengan proses evaluasi hasil belajar, sedangkan dari sisi siswa, hasil belajar merupakan berakhirnya penggal dan puncak proses belajar (Dimyati dan Mudjiono, 2009: 3). Dalam konteks pendidikan, guru mengajar supaya peserta didik dapat belajar dan menguasai isi pelajaran hingga mencapai suatu objektif yang ditentukan (aspek kognitif), juga dapat mempengaruhi perubahan sikap (aspek afektif), serta keterampilan (aspek psikomotor) seseorang peserta didik. Pengajaran memberi kesan hanya sebagai pekerjaan satu pihak, yaitu pekerjaan guru saja. Sedangkan pembelajaran juga menyiratkan adanya interaksi antara guru dengan peserta didik. Hasil belajar mencakup tiga ranah yaitu ranah kognitif, afektif, dan psikomotor dimana ketiga ranah tersebut saling berhubungan satu sama lain. Dalam penelitian ini hanya akan membatasi pada ranah kognitif yang meliputi aspek pengetahuan atau ingatan (C1), pemahaman (C2), aplikasi (C3), dan analisis (C4). Dari uraian di atas, dapat disimpulkan bahwa sebagai perubahan perilaku secara positif serta kemampuan yang dimiliki siswa dari suatu interaksi tindak belajar dan mengajar yang berupa hasil belajar intelektual, strategi kognitif, sikap dan nilai, inovasi verbal, dan hasil belajar motorik. Di sekolah hasil belajar di sekolah dapat dinyatakan dalam bentuk nilai atau hasil tes. Perubahan tersebut dapat diartikan terjadinya peningkatan dan pengembangan yang lebih baik dibandingkan dengan sebelumnya. Model pembelajaran Direct Instruction merupakan salah satu model pembelajaran kooperatif. Secara bahasa model pembelajaran Direct Instruction dapat diartikan sebagai pengajaran langsung. Akan tetapi banyak orang lebih suka mengganti kata pengajaran menjadi pembelajaran, sehingga Direct Instruction biasa juga disebut sebagai model pembelajaran langsung. Model pembelajaran Direct Instruction ini dapat digunakan dalam berbagai mata pelajaran dan tentunya dengan kemasan dan kreatifitas guru. Robert E Slavin dalam bukunya Educational Psychology dari Jhon Hopkins University Boston mendefinisikan bahwa Direct Instruction sebagai pendekatan mengajar dimana pembelajaran berorientasi pada tujuan pembelajaran dan distrukturisasi oleh guru. Jadi model pembelajaran langsung merupakan sebuah model pembelajaran yang bersifat teacher centered atau pembelajaran yang berpusat pada guru. Saat melaksanakan model pembelajaran ini, guru harus mendemonstrasikan pengetahuan dan keterampilan yang aklan dilatihkan kepada siswa selangkah demi selangkah. Karena itu dalam model pembelajaran ini guru harus dapat menjadi model yang menarik bagi siswa.Direct Instruction ketika dipraktikkan di dalam kelas, sangat erat berkaitan dengan metode ceramah walau sebenarnya tidak sama. Model 
pembelajaran langsung menuntut siswa untuk mempelajari suatu keterampilan dasar dan memperoleh informasi yang disampaikan oleh guru selangkah demi selangkah. Model pembelajaran Direct Instruction mempunyai karakteristik atau ciri-ciri tersendiri. Berikut merupakan ciri dari model pembelajaran langsung DI adanya suatu pembelajaran dan pengaruh model pada siswa termasuk penilaian hasil belajar, adanya sintaks atau pola keseluruhan kegiatan pembelajaran, adanya system pengelolaan dan lingkungan belajar model yang diperlukan agar kegiatan pembelajaran dapat berlangsung dengan baik.Setiap model pembelajaran harus dipersiapkan dengan baik agar proses pembelajaran dapat berlangsung efektif, tanpa persiapan yang matang pembelajaran apapun akan membuat siswa menjadi jenuh. Model belajar dan pembelajaran juga harus berganti-ganti dalam beberapa pertemuan agar belajar tidak monoton di dalam kelas. Langkah langkah pelaksanaan pembelajaran langsung DIdapat digambarkan sebagai berikut (1) Guru menyampaikan tujuan pembelajaran mempersiapkan siswa. Pada fase pertama ini gurumenjelaskan tujuan pembelajaran khusus, memberikan informasi tentang latar belakang pembelajaran, memberikan informasi mengapa pembelajaran itu penting, dan mempersiapkan siswa baik secara fisik ataupun mental untuk memulai pembelajaran. (2). Mendemonstrasikan pengetahuan atau kemampuan. Pada fase kedua ini guru berperan sebagai model dengan mendemonstrasikan pengetahuan atau keterampilan secara benar, guru harus menyajikan informasi secara bertahap selangkah demi selangkah sesuai struktur dan urutan yang benar. (3). Membimbing pelatihan.Pada fase ketiga ini guru harus memberikan bimbingan dan pelatihan awal agar siswa dapat menguasai pengetahuan dan keterampilan yang sedang diajarkan.(4) Mencek pemahaman dan memberikan umpan balik. Pada fase ini guru melakukan pengecekan apakah siswa dapat melakukan tugas dengan baik, apakah mereka telah menguasai pengetahuan dan keterampilan, dan selanjutnya member umpan balik yang tepat. (5). Memberikan kesempatan untuk pelatihan lanjutan dan penerapan. Pada fase ini guru menyediakan kesempatan kepada siswa untuk melakukan latihan lanjutan, dengan perhatian khusus pada penerapan kepada situasi yang lebih komplek atau penerapan pada kehidupan sehari hari. (6) Guru menyampaikan kesimpulan. Di akhir pembelajaran, guru bersama siswa mengambil kesimpulan sebagai penguatan materi pelajaran. Kelebihannya adalah sebagai berikut: Guru dapat memonitor perkembangan siswa; Guru mengendalikan isi materi dan urutan informasi yang diterima oleh siswa; Model ini dapat diterapkan di dalam kelas besar ataupun kecil; Dapat menjadi cara yang efektif untuk mengajarkan informasi dan pengetahuan faktual yang sangat terstruktur; Materi yang disampaikan guru lebih banyak walaupun waktunya singkat; Siswa yang malu bertanya bisa memperoleh informasi materi dari guru lebih banyak; Dapat bermanfaat untuk menyampaikan pengetahuan yang tidak tersedia secara langsung bagi siswa, termasuk contoh-contoh yang relevan dan hasil-hasil penelitian terkini.Adapun kekurangan dalam pembelajaran DIadalah:Siswa kurang berperan aktif dalam proses pembelajaran; Guru sulit memantau perkembangan siswa karena siswa kurang aktif; Siswa dapat merasa bosan karena siswa hanya mendengarkan ceramah guru; Guru satu-satunya sumber belajar.

Berdasarkan latar belakang dan identifikasi masalah di atas maka dapat dirumuskan permasalahan ini sebagai berikut: Apakah Melalui Penggunaan Model Pembelajaran Kooperatif DI dapat meningkatkan hasil belajar IPA Ciri-Ciri Makhluk Hidup Siswa Kelas III SDN Nguter 01 Sukoharjo Semester I Tahun Pelajaran 2019/2020. Merujuk pada perumusan masalah di atas, maka tujuan dilakukannya penelitian ini adalah Meningkatkan 
hasil belajar IPA materi ciri-ciri makhluk hidup pada siswa kelas III SDN Nguter 01 Sukoharjo Semester I Tahun Pelajaran 2019/2020 melalui penerapan pembelajaran DI.

\section{Metode Penelitian}

Penelitian dilaksanakan di kelas III semester ISDN Nguter 01 Sukoharjo semester I tahun pelajaran 2019/2020. Pemilihan lokasi dilandasi adanya pertimbangan bahwa peneliti adalah guru di sekolah tersebut sehingga memudahkan dalam pelaksanaan penelitian. Penelitian dilaksanakan pada semester 1 tahun pelajaran 2019/2020 selama 5 (lima) bulan, yaitu dimulai pada bulan Agustus 2019 sampai dengan bulan Desember 2019. Adapun jadwal pelaksanaan penelitian tindakan kelas adalah siklus I Pertemuan pertama dilaksanakan pada hari Kamis, 22 Agustus 2019, pertemuan kedua masih pada siklus yang sama dilakukan pada hari Jumat, 23 Agustus 2019, sedangkan Siklus II pertemuan pertama pada hari Rabu, 11 September 2019 dan pertemuan keduanya pada hari Kamis, 12 September 2019. Subjek dalam penelitian ini adalah siswa kelas III semester I SDN Nguter 01, Sukoharjo tahun pelajaran 2019/2020 yang terdiri dari 20 orang siswa. Pemilihan subjek dilandasi adanya alasan bahwa siswa kelas III belum mencapai ketuntasan belajar dalam pembelajaran IPAciri-ciri makhluk hidup. Data yang dikumpulkan dalam penelitian ini berupa aktivitas belajar siswa dan hasil belajar siswa dalam pembelajaran IPAciri-ciri makhluk hidup data dalam penelitian ini dikumpulkan dari berbagai sumber meliputiInforman atau nara sumber, yaitu siswa dan guru kelas III SDN Nguter 01 Sukoharjo, semester I tahun pelajaran 2019/2020.Tempat atau lokasi berlangsungnya proses pembelajaran IPAciri-ciri makhluk hidup; dan Dokumen atau arsip yang antara lain berupa kurikulum, rencana pelaksanaan pembelajaran, dan buku penilaian. Teknik pengumpulan data pada penelitian ini melalui teknik observasi, teknik tes, dan analisis dokumen. Adapun jenis tes dalam penelitian adalah tes hasil belajar, dan tes kecerdasan. Teknik tes dilakukan untuk mengumpulkan data hasil belajar siswa dalam pembelajaran IPA materi ciri-ciri makhluk hidup. Observasi digunakan dalam penelitian ini untuk mengetahui kondisi/interaksi belajar mengajar, tingkah laku, dan interaksi di dalam kelompok. Teknik dokumen dilakukan untuk mengkaji kurikulum, rencana pelaksanaan pembelajaran, dan buku penilaian yang dilakukan guru dalam pembelajaran IPA materi "Ciri-ciri makhluk hidup" bagi siswa kelas III SDN Nguter 01, Sukoharjo, Semester ITahun Pelajaran 2019/2020. Teknik yang digunakan dalam pemeriksaan validitas data antara lain adalah menggunakan teknik triangulasi, dan memperpanjang masa pengamatan.Analisis data dalam penelitian ini menggunakan teknik analisis deskriptif kualitatif - kuantitatif. Analisis data secara kualitatif digunakan untuk menganalisis data kualitatif, seperti hasil observasi dan studi dokumentasiAnalisis data deskriptif kuantitatif digunakan untuk menganalisa data kuantitatif, seperti hasil tes. Data kuantitatif berupa nilai hasil belajar siswa. Prosedur PTK ini mnegikuti prinsip-prinsip PTK, yaitu terdiri dari beberapa tahap diantaranya; tahap planning (rencana tindakan), implementing (tindakan), observing (observasi), dan reflecting (refleksi) yang kemudian diikuti dengan perencanaan ulang pada siklus kedua, dan seterusnyaPenelitian tindakan ini dilaksanakan dalam dua siklus tidakan dan dilaksanakan sesuai dengan perubahan yang ingin dicapai. Siklus pertama dilaksanakan 2 kali pertemuan dan siklus kedua juga dilaksanakan selama dua kali pertemuan. Tahapantahapan yang dilakukan pada setiap siklus terdiri dari 4 tahapan, yaitu: perencanaan, pelaksanaan, pengamatan, dan refleksi hasil tindakan. Pada saat kegiatan pembelajaran berlangsung guru kelas III sebagai observer melakukan pengamatan mengenaiaktivitas 
siswa selama pembelajaran berlangsung. Hasil catatan observasi bermanfaat untuk pengambilan keputusan dalam kegiataan selanjutnya yaitu refleksi. Hasil yang didapatkan dalam tahap observasi dikumpulkan serta dianalisis demikian pula hasil evaluasinya, apakah kegiatan yang telah dilakukan dapat meningkatkan aktivitas belajar dan hasil belajar siswa. Hasil analisis pada tahap ini digunakan sebagai acuan untuk melaksanakan siklus selanjutnya. Indikator keberhasilan dalam penelitian ini terdiri dari indikator aktivitas belajar dan hasil belajar. Pembelajaran dianggap berhasil apabila jumlah siswa yang sudah mencapai ketuntasan belajar dengan KKM $\geq 70$ sudah mencapai $>80 \%$ dari jumlah siswa

\section{Hasil Penelitian}

Data refleksi kondisi awal pelaksanaan kegiatan kondisi awal dalam penelitian ini dilakukan dengan mengumpulkan data dari wawancara yang telah dilakukan oleh penelitian dengan subjek terkait dengan strategi, model atau media pembelajaran yang digunakan waktu pembelajaran IPA dan hasil belajar siswa kelas III SDN Nguter 01 Sukoharjo terhadap materi ciri-ciri makhluk hidup dapat dijelaskan bahwa pembelajaran yang digunakan adalah ceramah, diskusi dan penugasan. Kendala ketika mengajar IPA yaitu ada beberapa siswa hasil belajarnya masih belum mencapai KKM yang telah ditentukan oleh sekolah. Hal ini dapat dilihat dari hasil belajar siswa pada materi ciri-ciri makhluk hidup, ada beberapa siswa yang mendapat nilai di bawah kriteria ketuntasan minimal (KKM) yaitu 70 , sebanyak $25 \%$ atau 7 siswa mendapat nilai di bawah KKM sedangkan 65\% dari jumlah keseluruhan siswa yang ada atau 13 siswa dari 20 siswa yang mendapat nilai diatas KKM.. Dari keterangan di atas dapat ditarik kesimpulan bahwa tingkat hasil belajar siswa kelas III SDN Nguter 01 Sukoharjo pada mata pelajaran IPA materi ciri-ciri makhluk hidup di bawah rata-rata atau rendah. Data pengamatan ketuntasan hasil belajar siswa pada siklus pertama diukur dengan memberikan tes pada siswa setelah dilakukan tindakan. Tujuan dari pemberian tes ini dimaksudkan untuk mengetahui sejauh mana hasil belajar siswa setelah dilakukan tindakan. Setelah selesai melaksanakan penelitian tindakan pada siklus I, guru bersama dengan penulis melakukan refleksi perolehan nilai dan ketuntasan belajar siswa kondisi awal dan siklus I Berdasarkan refleksi siklus menunjukkan bahwa nilai terendah adalah 60, sedangkan nilai tertinggi 90 dan rata rata nilai pada siklus I adalah 71,50. Dari semua data pada tabel dan diagram ketuntasan belajar siklus I di atas terlihat nilai siswa yang mencapai KKM atau tuntas ada 15 siswa dari 20 siswa. Prosentase ketuntasan belajar sebesar $75 \%$ dan $25 \%$ belum tuntas hal ini menunjukkan adanya peningkatan penguasaan materi dari perbaikan pembelajaran siklus I dibanding kondisi awal. Berdasarkan refleksi siklus I dapat diperoleh kesimpulan bahwa hasil analisis hasil belajar siswa masih rendah, karena masih terdapat 5 siswa, (25\%) siswa dari 20 siswa belum tuntas. Dari keseluruhan pengamatan yang dilakukan, maka guru dan penulis sepakat penelitian ini berlanjut ke siklus II. Pada akhir tindakan siklus II diperoleh data nilai terendah adalah 70, sedangkan nilai tertinggi 100 dan rata rata nilai pada siklus I adalah 80,5. Dari semua data pada tabel dan diagram ketuntasan belajar siswa siklus II di atas terlihat nilai siswa yang mencapai KKM atau tuntas ada 20 siswa dari 20 siswa. Prosentase ketuntasan belajar sebesar $100 \%$. Hal ini menunjukkan adanya peningkatan penguasaan materi pada siklus II dari perbaikan pembelajaran pada kondisi awal dan siklus I. Berdasarkan hasil refleksi pada Siklus II dapat diperoleh refleksi hasil pembelajaranIPA materi ciri-ciri makhluk hidupdengan menggunakan model pembelajaran DIpada siklus II menunjukkan bahwa pada siklus II secara klasikal ada peningkatan hasil belajar siswa. 
Siswa yang memperoleh nilai $\geq 70$ meningkat menjadi sebesar $100 \%$ dan aktivitas belajar siswa juga meningkat. Hal tersebut menunjukkan bahwa pada siklus II secara ada peningkatan yang signifikan dari hasil nilai siswa dan partisipasi siswa. Hasil tes siswa ratarata pada kondisi awal sebesar 68, pada siklus I sebesar 71,5 dan pada siklus II sebesar 80,5. Sedangkan presentase siswa yang mencapai KKM pada kondisi awal sebesar $65 \%$, siklus I sebesar $75 \%$ dan siklus II sebesar $100 \%$. Jadi terdapat peningkatan rata-rata dan presentase siswa yang telah mencapai KKM dari kondisi awal, siklus I, dan siklus II. Terjadi peningkatan nilai rata-rata dari kondisi awal sampai tindakan pada siklus II sebesar 12, 5, selain peningkatan nilai rata-rata pada ketuntasan belajarpun juga mengalami peningkatan dari kondisi awal ketuntasan belajar $65 \%$ pada siklus II menjadi $100 \%$ terjadi peningkatan sebesar 35\%, maka guru atau peneliti tidak melanjutkan kegiatan pembelajaran ke siklus berikutnya karena apa yang sudah dicapai dianggap memuaskan, atau dengan kata lain penerapan model pembelajaran DI telah meningkatkan hasil belajar IPA materi ciri-ciri makhluk hidup siswa kelas III SDN Nguter 01 Sukoharjo Semester I tahun pelajaran 2019/2020. Tabel perolehan nilai dan ketuntasan belajar siswa kondisi awal, siklus I dan siklus II adalah sebagai berikut:

Tabel 1 Perolehan Nilai dan Ketuntasan Belajar

\begin{tabular}{clccc} 
No & \multicolumn{1}{c}{ Uraian } & Kondisi Awal & Siklus I & Siklus II \\
1 & Nilai Tertinggi & 80 & 90 & 100 \\
2 & Nilai Terendah & 60 & 60 & 70 \\
3 & Nilai rata-rata & 68 & 71,50 & 80,5 \\
4 & Nilai tuntas & $13(65 \%)$ & $15(75 \%)$ & $20(100 \%)$ \\
5 & Nilai tidak tuntas & $7(35 \%)$ & $5(25 \%)$ & $0 \%$ \\
\hline
\end{tabular}

Data yang diperoleh mengenai ketuntasan hasil belajar IPA Ciri ciri makhluk hidup dengan menggunakan pembelajaran DI dapat dilihat pada diagram dibawah ini:

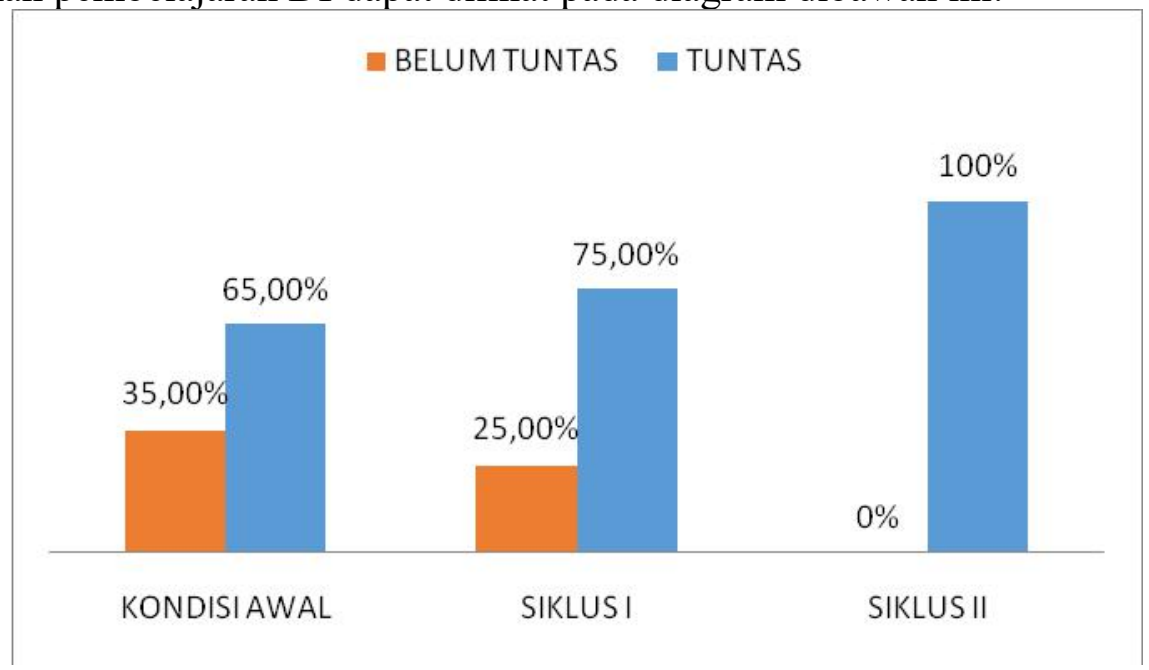

Gambar 1 Diagram Perbandingan Ketuntasan Siswa Tiap Siklus

Dengan demikian hipotesis tindakan penelitian tindakan kelas ini bahwa "Melalui Penerapan Pembelajaran DIdi duga dapat meningkatkan dapat hasil belajar IPA Ciri-ciri makhluk hidup Pada Siswa Kelas III SDN Nguter 01 Sukoharjo Semester I Tahun Pelajaran 2019/2020, terbukti kebenarannya". 


\section{Pembahasan}

Hipotesis tindakan yang menyatakan bahwa Melalui Penerapan Pembelajaran DI di duga dapat meningkatkan dapat hasil belajar IPA Ciri-ciri makhluk hidup Pada Siswa Kelas III SDN Nguter 01 Sukoharjo Semester I Tahun Pelajaran 2019/2020, terbukti kebenarannya. Hasil penelitian yang telah dilakukan oleh Garnawati Siregar (2016) pada siswa kelas IVA SDN 015 Sungai Salak Kecamata Tempuling juga membuktikan bahwa terjadi peningkatan daya serap dari hasil ulangan siklus I adalah 61.00 (baik) dan hasil ulangan harian siklus II 82.50 (baik). Ketuntasan belajar baik secara individual maupun klasikal mengalami peningkatanpada siklus I sebnayak 12 siswa dan siklus II sebanyak 19 siswa. Penelitian juga pernah dilakukan oleh Edo Dwi Cahyono (2018) pada mata pelajaran IPS penelitian tersebut menunjukkan hasil bahwa model pembelajaran Direct Instruction juga dapat mempermudah guru dalam melaksanakan pembelajaran. Penelitian serupa juga dilakukan oleh Siti Munawaroh (2017) penelitian tersebut menunjukkan hasil bahwa penggunaan model direct instruction dapat meningkatkan hasil belajar IPA siswa kelas IV B SD Negeri 2 Babakanreuma.

Dari hasil penelitian diperoleh hasil ulangan evaluasi yang didapatkan siswa pada tahapan siklus mengalami peningkatan dari tahapan awal di kondisi awal meningkat di Siklus I kemudian mengalami peningkatan kembali di Siklus II. Ketuntasan belajar siswa meningkat pula. Pelaksanaan pembelajaran yang dilaksanakan pada siklus I dan II berjalan dengan baik. Hal tersebut dapat dilihat pada kenaikan nilai aktivitas belajar siswa pada siklus I meningkat pada siklus II. Peningkatan rata-rata nilai evaluasi pada kondisi awal 68 menjadi 71,5 pada siklus I dan meningkat kembali menjadi 80,5 pada siklus II, terjadi peningkatan rata-rata nilai tes evaluasi dari kondisi awal sampai siklus II sebesar 12,5.hasil belajar siswa berhasil dibuktikan dengan kenaikan hasil belajar siswa yang tuntas. Persentase siswa yang tuntas pada kondisi awal sebesar $65 \%$, pada siklus I sebesar $75 \%$ dan pada siklus II menjadi 100\%. Peningkatan presentase ketuntasan dari kondisi awal sampai akhir tindakan siklus II meningkat sebesar 35\%.

\section{Simpulan dan Saran}

Berdasar hasil analisis data dan pembahasan tentang Penggunaan Model Pembelajaran Kooperatif DI dalam Meningkatkan Hasil Belajar IPA Ciri-Ciri Makhluk Hidup Siswa Kelas III SDN Nguter 01 Sukoharjo Semester I Tahun Pelajaran 2019/2020 dapat disimpulkan sebagai berikut: "Melalui Pembelajaran DI dapat meningkatkan hasil belajar IPA Ciri-Ciri Makhluk Hidup Siswa Kelas III SDN Nguter 01 Sukoharjo Semester I Tahun Pelajaran 2019/2020. Terjadi peningkatan nilai rata-rata sebesar 12,5 dan peningkatan ketuntasan sebesar 35\% dari kondisi awal samp Winataputra, Udin. 2005. Strategi Belajar Mengajar. Jakarta: Universitas Terbuka ai pada akhir siklus II ".Sesuai dengan hasi penelitian maka sebagai tindak lanjut dan kesempurnaan maka dikemukakan saransaran antara lain guru hendaknya menerapkan model pembelajaran DI sebagai pertimbangan dan alternatif model pembelajaran IPA yang dapat memberikan pengalaman bermakna serta meningkatkan hasil belajar siswa.Guru disarankan untuk melakukan tindak lanjut terhadap penggunaan model pembelajaran DI dapat diterapkan di sub pokok bahasan yang lain.Guru hendaknya lebih banyak mempelajari model-model pembelajaran lain yang 
bersifat aktif dan kreatif. Siswa hendaknya mampu bekerja sama dengan siswa yang lain dalam pembelajaran dengan model pembelajaran DI sehingga dapat berjalan dengan lancar.Kepala Sekolah hendaknya tetap memfasilitasi demi kelancaran proses pembelajaran.Kepala Sekolah hendaknya ikut berpartisipasi dalam proses pembelajaran.

\section{Daftar Rujukan}

Arikunto, S. (2010). Prosedur Penelitian: Suatu Pendekatan Praktek. Jakarta: Rineka Cipta Revisi.

Avikasari. (2015). Peningkatan Kualitas Pembelajaran IPA Melalui Model Direct Instruction (DI) Dengan Media Audiovisual Pada Siswa Kelas V SDN Gunungpati 02 Semarang. Jurnal Theory Intro Practice.

Djamarah, Syaiful Bahri dan Aswan Zain. (2010). Strategi Belajar Mengajar. Jakarta: Rineka Cipta.

Dimyati dan Mudjiono. (2009). Belajar dan Pembelajaran. Jakarta: PT Rineka Cipta. Edo Dwi Cahyono. (2018). Penggunaan Model Pembelajaran Direct Instruction Untuk Mengingkatkan Hasil Belajar Siswa Pada Pelajaran Ilmu Pengetahuan Sosial. Jurnal Penelitian Ilmiah, volume 3(1), hal: 10-20.

Garnawati Siregar (2016). Penggunaan Direct Instruction Model Untuk Meningkatkan

Hasil Belajar IPA Pada Materi Tumbuhan Dan Fungsinya Siswa Kelas IV A SDN 015

Sungai Salak Kecamatan Tempuling. Jurnal Primary, volume 5(1), hal: 30-40.

Hamalik, Oemar. (2006). Proses Belajar Mengajar. Jakarta: PT Bumi Aksara. . (2010). Proses Belajar Mengajar. Bandung: Bumi Aksara.

Sardiman. (2010).Interaksi dan Motivasi Belajar Mengajar. Jakarta: Rajawali Pers.

Sudjana, Nana. (2010). Penilaian Hasil Proses Belajar Mengajar. Bandung: PT. Ramaja

Rosdakarya.

Siti Munawaroh. (2017). Upaya Meningkatkan Hasil Belajar IPA Melalui Model Direct

Instruction Pada Siswa Kelas IV B SD Negeri 2 Babakanreuma. Pedagogi: Jurnal

Pendidikan, volume 4(1), hal: 50-60.

Slameto. (2010). Belajar dan Faktor yang mempengaruhinya. Jakarta: Rineka. Cipta.

Suprapti Hariyani. (2019). Peningkatan Aktivitas dan Hasil Belajar IPA Materi Sistem

Ekskresi Manusia melalui Model Pembelajaran Discovery Learning dan Metode Eksperimen Siswa Kelas VIII G SMP Negeri 1 Boyolali pada Semester Genap Tahun

Pelajaran 2018-2019. Jurnal Pendidikan, volume 28(3), hal: 339-352.

Suprijono, Agus. (2010). Cooperative Learning. Yogyakarta: Pustaka Pelajar.

Susanto. (2013). Teori Belajar dan Pembelajaran di Sekolah Dasar. Jakarta: Kencana

Prenada Media Group.

Sutikno. (2013). Belajar dan Pembelajaran. Lombok: Holistica Lombo.

Suwarto, S. (2017). Pengembangan tes ilmu pengetahuan alam terkomputerisasi. Jurnal Penelitian dan Evaluasi Pendidikan, 21(2), 153-161.

Slavin, Robert E. (2005). Cooperative Learning Teori, Riset dan Praktik. Bandung: Nusa Media.

Wahidmurni, Alifin Mustikawan, dan Ali Ridho. (2010). Evaluasi Pembelajaran: Kompetensi dan Praktik. Yogyakarta: Nuha Letera.

Wiriaatmadja, R. (2006). Metode Penelitian Tindakan Kelas Untuk Meningkatkan Kerja Guru dan Dosen. Bandung: Remaja Rosdakarya 